\title{
HEART RATE REACTION OF BASKETBALL PLAYERS UNDER ENDURANCE TRAINING
}

\author{
ALTERAÇÃO DA FREQUÊNCIA CARDÍACA DE JOGADORES DE BASQUETEEM TREINO DE RESISTÊNCIA \\ ALTERACIÓN DE LA FRECUENCIA CARDÍACA DE JUGADORES DE BÁSQUETEN ENTRENAMIENTO DERESISTENCIA
}

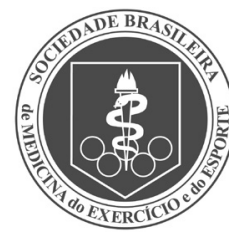

Original Article

ARTIGO ORIGINAL

Artículo Original
Chuanmin Wang ${ }^{1}$ (ID

(Physical Education Professional)

1. Xinyang Vocational and

Technical College, Xinyang, Henan,

China.

\section{Correspondence:}

Chuanmin Wang

Xinyang, Henan, China. 464000.

wangchuanmin7@126.com

\begin{abstract}
Introduction:In the current Chinese basketball team, many players have a high level of training. However, in official competitions, athletes tend to have heart rate problems. Therefore, it is importment to monitor and control the heart rate of basketball players to improve their performance. Objective:To explore the heart rate of basketball players in intermittent endurance training. Methods: The researchers selected 28 male basketball players from a university as the research objects. Athletes performed intermittent endurance training, and their heart rate variability, changes in frequency indicators, and changes in cardiac function were measured before and after training. Results: After training,(Total Power,TP), (High Frequency,HF), HFnorm, and (Low Frequency,LF) were significantly higher than before training. The effect sizes were medium for TP (0.7); moderate for $\mathrm{HF}(0.72)$; medium for HFnorm (0.59); and moderate for $L F n o r m ~(0.57)$. In the case of $L F / H F$ and $L F$, the effect size was 0.48 , close to the critical value of medium effect. Conclusions: Intermittent endurance training can improve the tension of the cardiovagal nerve of college basketball players and increase heart capacity and load, significantly improving heart function. Level of evidence Il; Therapeutic studies - investigation of treatment results.
\end{abstract}

Keywords: Physical Education and Training; Basketball; Heart Rate.

\section{RESUMO}

Introdução: Muitos jogadores têm um alto nível de treinamento na atual equipe chinesa de basquetebol. Contudo, os atletas tendem a ter problemas relacionados à frequência cardíaca em competições oficiais. Portanto, é importante monitorar e controlar o batimento cardíaco visando obter a melhora de desempenho nos jogadores. Objetivo: Investigar o batimento cardíaco dos jogadores de basquetebolem treinamentos intermitentes de resistência. Métodos: Os pesquisadores selecionaram 28 jogadores de basquete em uma universidade como objeto de estudo. Esses atletas realizaram treinamento de resistência intermitente onde foram aferidas, antes e após do treino, a variabilidade de suas frequências cardíacas, as mudanças nos indicadores de frequência e as mudanças na função cardíaca. Resultados: Após o treinamento, a Potência Total (TP), a Alta Frequência (HF), a HFnorm e a Baixa Frequência (LF) foram significativamente mais altas que as aferidas previamente ao treino. O nível de alteração foi médio para $\operatorname{TP}(0,7)$, moderado para $\operatorname{HF}(0,72)$, médio para HFnorm $(0,59)$ e moderado para LFnorm (0,57). No caso de LF/HF e LF, o tamanho da alteração foi de 0,48, próxima ao valor crítico do efeito médio. Conclusões: O treinamento de resistência intermitente pode melhorar a resistência do nervo cardiovagal nos jogadores universitários de basquete, aumentar a capacidade cardíaca e melhorar significativamente a função cardíaca. Nível de evidência ll; Estudos terapêuticos - investigação de resultados de tratamento.

Descritores: Educação Física e Treinamento; Basquetebol; Frequência Cardíaca.

\section{RESUMEN}

Introducción: Muchos jugadores tienen un alto nivel de entrenamiento en el actual equipo chino de baloncesto. Sin embargo, los atletas tienden a tener problemas relacionados a la frecuencia cardiaca en competiciones oficiales. Por lo tanto, es importante monitorear y controlar la frecuencia cardíaca con el fin de obtener mejoría de desempeño en los jugadores. Objetivo: Investigar la frecuencia cardiaca en los jugadores de baloncesto en entrenamientos intermitentes de resistencia. Métodos: Los investigadores seleccionaron 28 jugadores de baloncesto en una universidad como objeto de estudio. Estos atletas realizaron entrenamiento de resistencia intermitente donde fueron medidas, antes y después del entrenamiento, la variabilidad de sus frecuencias cardíacas, los cambios en los indicadores de frecuencia y los cambios en la función cardíaca. Resultados: Después del entrenamiento, la Potencia Total (TP), I Alta Frecuencia (HF), la HFnorm y la Baja Frecuencia (LF) fueron significativamente más altas que las mediciones previas al entrenamiento. El nivel de alteración fue medio para TP $(0,7)$, moderado para $H F(0,72)$, medio para HFnorm $(0,59)$ y moderado para $L F n o r m(0,57)$. En el caso de LF/HFy LF, el tamaño de la alteración fue de 0,48, cercana al valor crítico del efecto medio. Conclusiones: El entrenamiento de resistencia intermitente puede mejorar la resistencia del nervio cardiovagal en los jugadores universitarios de baloncesto, aumentar la capacidad cardíaca y mejorar significativamente la función cardíaca.. Nivel de evidencia ll; Estudios terapéuticos - investigación de resultados de tratamiento.

Descriptores: Educación y Entrenamiento Físico; Baloncesto; Frecuencia Cardíaca. 


\section{INTRODUCTION}

In the current Chinese basketball team, many athletes usually train at a higher level, the technology has been used well, but in the official competition, especially in fierce competitions with considerable strength, the technical level is out of order.' In the heavy exercise training class, some exercises, on the surface, practice the players to a greater degree, but ignoring the rotation relationship between the players, thus lengthening the interval time, make the whole degree at a lower level. ${ }^{2}$ Undeniable, exercise intensity is a problem that all coaches attach great importance to in basketball training. In most of the heavy exercise training classes of the survey subjects, have a considerable degree, and the heart rate has reached a high level, however, the heart rate below 20 times/10" in the heavy exercise training class accounts for $86-14.3 \%$ of the class time. ${ }^{3}$ Long pauses and multiple pauses, decrease the heart rate and increase the fluctuation of the heart rate interval, its balanced heart rate is affected by the low heart rate during long intermittent periods, which is the root cause of the lower level. Therefore, the length of the interval not only affects the maintenance of the heart rate level, it is also meaningful to the formation of the heart-ze curve trend. ${ }^{4}$ In a training class with a certain level, short intervals and multiple intervals will inevitably make the heart-timing curve unrecovered, the formation of the combination of long and short intervals will inevitably bring the heart rate curve to a preliminary recovery state, based on the above situation, there are reasons to believe that, long intervals during high-volume training are the prominent cause of the drop in heart rate. ${ }^{5}$

\section{METHOD}

\section{Research objects}

The subjects were 28 male basketball players from a certain university. The basic information is shown in Table 1.

\section{Experimental method}

Carry out 8 weeks of intermittent endurance training, monitor the athlete's training load and interval time, strictly control the intermittent heart rate. ${ }^{6}$ Before and after training, use safe and effective, and the experimental equipment that does not have any damage to the athletes can detect the relevant indicators of the athletes' physiological functions, a comparative analysis of various indicators before and after training.?

\section{Interval endurance training content}

\section{(1) Training method}

Using the intermittent running training method, during training, strictly control the heart rate during the interval, ensure that the interval between each time can restore the athlete's heart rate to 120-130 beats/min, do the next set of training, use positive recovery methods during intermittent periods. The training content is divided into two parts, the first part is basic training and resistance training, The second part is physical fitness and technical and tactical coordination. According to the heart rate value displayed by the polar meter during training, monitor the athlete's heart rate. Basic training and technical and tactical training will take a break when the heart rate reaches 160-170 beats/min, resist resistance training and physical fitness training should rest when the heart rate reaches 180-190 beats/min.

\section{(2) Heart rate variability test method}

The subject is lying flat, perform limb leads. Apply conductive liquid to the conductive clip, then clamp the conductive clip on the left wrist of the subject in the order of yellow, green, red, and black and about $2-3 \mathrm{~cm}$ above the left ankle, about $2-3 \mathrm{~cm}$ above the right wrist and right ankle.

Table 1. Basic information of subjects.

\begin{tabular}{c|c|c|c}
\hline Sample size & Age & Weight & Height \\
\hline 28 & $20-22$ & $84.61-98.12$ & $188.93-193.65$ \\
\hline
\end{tabular}

\section{RESULTS}

\section{Changes in time domain indicators of heart rate variability}

As shown in Figure 1, after training, the time domain indicators RMSSD, SDSD, PNN50, and SDNN are all significantly higher than before training, the differences are statistically significant. It shows that basketball players'vagus nerve regulation ability is enhanced after training. SDNN represents the overall regulation ability of the sympathetic nerve and the vagus nerve; The three indicators of RMSSD, SDSD and PNN50 all reflect the magnitude of vagus nerve tension. The increase in SDNN does not completely represent the enhancement of the athlete's sympathetic nerve regulation ability, therefore, it is necessary to use the frequency domain index for in-depth discussion. And the effect size of RMSSD $=0.65$, showing a moderate effect; The effect size of SDSD $=0.79$, showing a moderate effect; The effect size of PNN50 =0.80, showing a high effect, it can be considered that the above indicators are greatly affected by the independent variable intermittent endurance training. ${ }^{8}$

\section{Changes in the frequency domain index of heart rate variability}

As shown in Table 2, after training, TP, HF, HFnorm, and LF are significantly higher than before training, the differences are statistically significant, there was no significant difference in VLF, LF/HF and LFnorm are significantly lower than before training, the differences are statistically significant. TP showed greater changes after training than before training, the test result is the same as the SDNN in the time domain index. It shows that the autonomic nerve regulation system has improved after training. HF increased significantly, the same as the results of RMSSD, SDSD, and PNN50 in the time domain indicator, shows that the athlete's vagus nerve regulation ability has been improved. The LF/HF index reflects the balance of mutual inhibition of vagus nerve and sympathetic nerve, after training is smaller than before training, at the same time LFnorm. decreases, HFnorm. increases, consistent with the changes in LF/HF, there are significant differences, it shows that basketball players' sympathetic vagus balance has a vagus trend after training, the control ability of the vagus nervous system

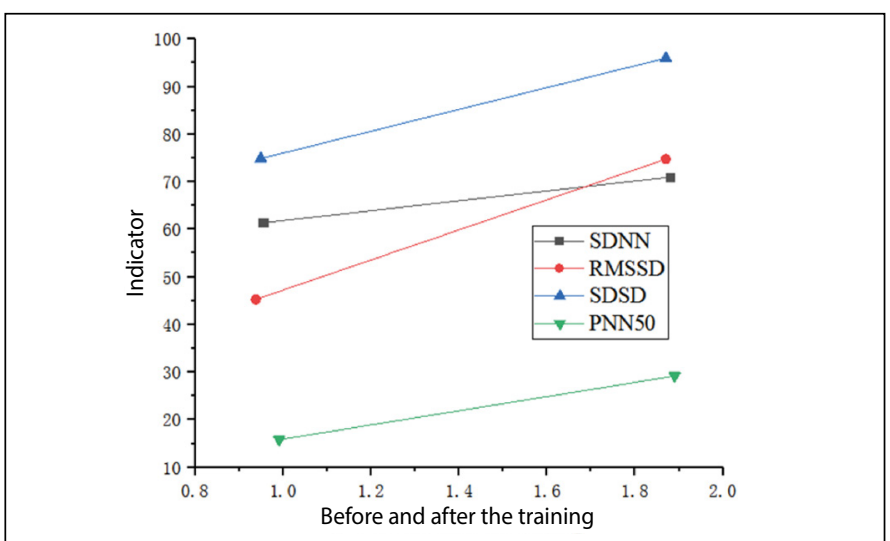

Figure 1. Changes in time-domain indicators of heart rate variability before and after training..

Table 2. Changes in the frequency domain index of heart rate variability before and after training.

\begin{tabular}{c|c|c}
\hline Index & Before training & After training \\
\hline TP & $1351.57 \pm 903.07$ & $2152.93 \pm 1356.81$ \\
\hline LF/HF & $1.19 \pm 1.42$ & $0.69 \pm 0.43$ \\
\hline HF & $667.50 \pm 583.74$ & $1131.35 \pm 705.10$ \\
\hline HFnorm & $54.43 \pm 17.24$ & $63.39 \pm 13.01$ \\
\hline LF & $500.97 \pm 358.48$ & $772.14 \pm 707.29$ \\
\hline$L F n o r m$ & $45.57 \pm 17.24$ & $36.86 \pm 12.77$ \\
\hline VLF & $183.10 \pm 164.90$ & $249.44 \pm 157.1$
\end{tabular}


is improved. And the effect size of TP $=0.7$, showing a medium effect; The effect size of $\mathrm{HF}=0.72$, showing a moderate effect; The effect size of HFnorm $=0.59$, showing a medium effect; The effect size of LFnorm $=0.57$, showing a moderate effect; The effect size of $L F / H F=0.48$, the effect size of $L F=0.48$, which is close to the critical value of medium effect, it can be considered, the above indicators are greatly affected by the independent variable intermittent endurance training.

\section{Changes in heart function}

As shown in Table 3, after training, Avag and SDAW were significantly higher than before training, the differences are statistically significant, Asym.TI is significantly lower than before training, the differences are statistically significant, no significant difference was seen in Aplnf. It shows that the central nervous system's regulation of heart activity is reduced after training, the training effect is significantly strengthened, the degree of fatigue is significantly reduced, and there is no significant change in the stress response, the cardiac function reserve increased significantly, the influence factor of the vagus nerve increases, the influence factor of sympathetic nerves is weakened, after training, the athlete's ability to regulate heart function has been significantly improved.

\section{DISCUSSION}

The analysis of heart rate variability (HRV) is divided into time domain analysis and frequency domain analysis, frequency domain analysis can make up for the deficiencies of time domain analysis, HRV

Table 3. Changes of cardiac function indexes before and after training.

\begin{tabular}{c|c|c}
\hline Index influence factor & Before training & After training \\
\hline Avag & $0.27 \pm 0.09$ & $0.32 \pm 0.09$ \\
\hline Asym & $36.43 \pm 10.12$ & $31.63 \pm 7.59$ \\
\hline TI & $87.30 \pm 63.31$ & $58.89 \pm 35.73$ \\
\hline Aplnf & $1.70 \pm 0.38$ & $1.62 \pm 0.27$ \\
\hline SDAW & $0.026 \pm 0.012$ & $0.031 \pm 0.008$ \\
\hline
\end{tabular}

is further analyzed on the basis of time domain analysis. ${ }^{9}$ SDNN in the time domain index reflects the overall activity level of sympathetic nerve and vagus nerve, used to evaluate the overall regulation ability of the cardiac autonomic nervous system, RMSSD reflects the level of regulation of the vagus nerve, SDSD reflects the level of vagus nerve regulation ability, PNN50 measures the ability of the vagus nerve to regulate heart rate variability. ${ }^{10}$ TP in the frequency domain index reflects the overall adjustment ability of the autonomic nervous system, $\mathrm{HF}$ reflects the level and change of the vagus nerve, LF mainly reflects the activity level of sympathetic nerves, VLF reflects the function of sympathetic nerve regulation, LF/HF reflects the balance index of sympathetic nerve and vagus nerve, HFnorm and LFnorm. indicate the changes of sympathetic nerve and vagus nerve. Avag reflects the tension of the heart function state, Asym reflects whether the heart function regulation mechanism is mobilized, $\mathrm{TI}$ reflects the tension index, ApInf reflects the strength of the stress response, SDAW reflects the level of function reserve.

\section{CONCLUSION}

The intermittent endurance training method can effectively improve the athlete's vagus nerve tension, the increase of the vagus nerve can effectively inhibit the excitability of the heart, reduce the number of heart beats, decrease heart rate. An increase in heart rate can lead to insufficient ventricular filling, this affects the pumping function of the heart, at the same time it will increase the energy consumption of the myocardium, easily cause myocardial fatigue. Therefore, the increase in excitability of the vagus nerve after training better inhibits the beating of the heart, reduce the production of myocardial fatigue, the fatigue index decreases, while the tension index decreases, play a good role in the functional reserve of the heart.

The author declare no potential conflict of interest related to this article

\section{REFERENCES}

1. Berkelmans DM, Dalbo VJ, Fox JL, Stanton R, Kean CO, Giamareos KE et al. Influence of Different Methods to Determine Maximum Heart Rate on Training Load Outcomes in Basketball Players. The Journal of Strength and Conditioning Research. 2017;32(11):1.

2. Dehesa R, Vaquera A, García-Tormo J, Bayón P. Heart rate analysis of high level basketball players during training sessions. Revista De Psicologia Del Deporte. 2015;24(1):17-9.

3. Nowak AM, Pytel A, Molik B, Marszalek J. Characteristics of injuries of young adult male basketball players. Advances in Rehabilitation. 2019;33(3):35-46.

4. Verma C, Subramanium L, Krishnan V. Effect of plyometric training on vertical jump height in high school basketball players: A randomised control trial. International Journal of Medical Research \& Health Sciences. 2015;4(1):7-12.

5. Ureña-Bonilla P, Blanco-Romero L, Sánchez-Ureña B, Salas-Cabrera J. Psychological characteristics and self-assessment of performance in costa rican soccer and basketball players of the first division. Cuadernos de Psicologia del Deporte. 2015;15(2):13-20.

6. Vasconcelos T, Hall A, Viana R. The influence of inspiratory muscle training on lung function in female basketball players - a randomized controlled trial. Porto Biomedical Journal. 2017;2(3):86-9.

7. Chen Z, Sun G, Hui L, Shi G. Study on Characteristics of Sliding Electrical Contact of Pantograph-catenary Under Fluctuating Pressure Load. Gaoya Dianqi/High Voltage Apparatus. 2018;54(12):82-8.

8. Eunae K. Study on the Distinct Characteristics of the IRB's Roles under the Bioethics and Safety Act in Korea and the Suggestions for the Amendment of the Provisions related to the IRB Operation: Focusing on the IRB of the Medical Institutions Producing Embryos, th. Bioethics Policy Studies. 2015;9(1):205-44.

9. Albaladejo-Saura M, Vaquero-Cristóbal R, Esparza F. Effect of preseason training on anthropometric and derived variables in professional basketball players. Retos: Nuevas Tendencias en Educación Física, Deporte y Recreación. 2019;36:474-479. 